\title{
Decay times of organic carbon in sedimented detritus in a macrotidal estuary
}

\author{
B. T. Hargrave, G. A. Phillips \\ Habitat Ecology Division, Biological Sciences Branch, Department of Fisheries and Oceans, Bedford Institute of Oceanography,
} PO Box 1006, Dartmouth, Nova Scotia, Canada B2Y 4A2

\begin{abstract}
Respiration rates of particulate matter, collected in sediment traps placed $1 \mathrm{~m}$ above the sediment during tidal cover at an intertidal site in the upper Bay of Fundy, Canada, were calculated from oxygen and carbon dioxide fluxes. Values decreased from $6 \mu \mathrm{g} \mathrm{C} \mathrm{g} \mathrm{g}^{-1}$ dry $\mathrm{wt} \mathrm{h}^{-1}$ during midsummer to $<0.5 \mu \mathrm{g} \mathrm{C} \mathrm{g}^{-1}$ dry wt $\mathrm{h}^{-1}$ in winter. Rates were positively correlated with seasonal changes in temperature with a coefficient equivalent to $\mathrm{Q}_{10}$ of 2 and with chlorophyll $a$ in settled material. The ratio of total organic carbon in detritus to daily respiration gave first-order decay constants (k) of 2 to $5 \mathrm{yr}^{-1}$ during summer and 0.3 to $1.3 \mathrm{yr}^{-1}$ during winter. Equivalent $95 \%$ decay times $(3 / \mathrm{k})$ were 200 to $500 \mathrm{~d}$ and 800 to $3800 \mathrm{~d}$, respectively. Respiration of labile organic carbon was calculated from organic carbon exceeding the seasonal minimum $(0.8 \% \mathrm{dry} w \mathrm{w})$ and chlorophyll a content. Lower decay times (20 to 40 d) during the summer coincided with low labile organic carbon: chlorophyll a ratios (30 to 50) indicative of freshly produced organic matter
\end{abstract}

\section{INTRODUCTION}

Studies in many shallow coastal areas such as the Dutch Wadden Sea (Cadée 1978), the Lyhner estuary (Joint 1978) and salt marshes along the Gulf of Mexico (Ribelin \& Collier 1979) have shown that the formation and transport of detrital aggregates are major processes for organic carbon flux. Aggregates are also intensive sites of organic matter production and consumption in oceanic waters (Azam et al. 1983, Alldredge \& Cohen 1987). In coastal waters of the Adriatic Sea, $70 \%$ of oxygen uptake and over $90 \%$ of total primary production was estimated to occur in marine snow aggregates (Herndl 1988). The abundance of suspended detritus was determined in all of these studies but no measures of turnover rates for organic matter in aggregates were made.

Although models to describe organic matter decomposition in aquatic systems have been proposed (Berner 1980, Westrich \& Berner 1984), decay rates of organic detritus are usually not determined because of lack of standard methodology. Olsen (1963) suggested an approach that describes the steady-state concentration of organic substrates in ecosystems as the ratio of the rate of supply (equal to respiratory loss at steadystate) to standing stock. Respiration (R) can be expressed as units of carbon (C) loss per time (t) where

$$
\mathrm{R}=\mathrm{dC} / \mathrm{dt}
$$

If $C$ is the steady state concentration of organic carbon, respiration can be described as a simple first-order decay $(k)$ proportional to organic carbon concentration present and

$$
-\mathrm{k}=\mathrm{R} / \mathrm{C}
$$

The rate of carbon loss through respiration is thus a function of the organic carbon concentration present in the detrital substrate described by the decay rate constant k. Integration of Eq. (2) over time as organic carbon content decreases to zero gives

$$
C(t)=C[\exp (-k t)]
$$

The simple exponential model can be used to express the decay time (DT) required for decomposition to consume a specific fraction of organic substrate where $f$ is the residual fraction. From Eq. (3)

$$
f=\exp (-k \mathrm{k})
$$

and

$$
\mathrm{DT}=-\ln (\mathrm{f}) / \mathrm{k}
$$

The time required to reach $95 \%$ of steady state concentrations (95\% decay time) is

$$
-\ln (0.05) / \mathrm{k}=3 / \mathrm{k}
$$


We used this approach to calculate organic carbon decay time for sedimented detritus collected in the Bay of Fundy, Canada. The location has been the site of inter-related seasonal studies of organic carbon flux through an intertidal area. Measurements of oxygen uptake (Hargrave et al. 1983) and nutrient release (Keizer et al. 1989) have been reported for detrital aggregates collected in sediment traps exposed for a period before and after high tide. Determinations of carbon dioxide release, oxygen uptake, particulate organic carbon, nitrogen and chlorophyll a in settled particles are reported here. Data are used to calculate first-order decay rates for detrital organic carbon as the ratio of organic carbon standing stock to respiratory carbon loss.

\section{MATERIALS AND METHODS}

Gordon et al. (1980) and Hargrave et al. (1983) described the sampling site in the upper intertidal zone at Pecks Cove, Cumberland Basin, at the head of the Bay of Fundy. Average tidal range is about $11 \mathrm{~m}$ (maximum spring tide of $14 \mathrm{~m}$ ). Except for brief periods of slack water (10 to $20 \mathrm{~min}$ ) current velocities over intertidal areas vary from 0.5 to $2 \mathrm{~m} \mathrm{~s}^{-1}$ (Gordon \& Desplanque 1983). Periodic measurements of drift ice movement at Pecks Cove (Hargrave unpubl.) showed the occurrence of a gyre that moved ice at higher velocities (up to $1 \mathrm{~m} \mathrm{~s}^{-1}$ ) offshore than over the inner intertidal area $\left(0.2\right.$ to $\left.0.5 \mathrm{~m} \mathrm{~s}^{-1}\right)$. Fine silt sediments with particles $<62 \mu \mathrm{m}$ are readily resuspended by tidal action and additionally during winter by ice scour. These processes create turbid water over intertidal areas throughout Cumberland Basin. Minimum concentrations of suspended particles $\left(100 \mathrm{mg} \mathrm{l}^{-1}\right)$ occur during August and highest values (> $300 \mathrm{mg} \mathrm{l}^{-1}$ ) in February.

Despite these differences in total concentrations of suspended material, modal inorganic grain size in suspension during high tide (10 to $16 \mu \mathrm{m}$ ) was similar between May and December ( $P$ Keizer unpubl.). Surface sediments throughout this period contained particles with a modal diameter of 20 to $40 \mu \mathrm{m}$. Coarser sediments (modal grain size 40 to $64 \mu \mathrm{m}$ ) occurred at a station in the lower intertidal zone (Gordon \& Desplanque 1983). The difference in grain size between the 2 sites is indicative of higher current velocities in the lower intertidal zone.

Duplicate cylinders $(5.6 \mathrm{~cm}$ i.d., $31.0 \mathrm{~cm}$ long) with open tops $1 \mathrm{~m}$ above the sediment, described in Hargrave et al. (1983), were exposed ( 3.5 to $4.5 \mathrm{~h}$ ) during high tide approximately once per month (except during ice cover) between spring and winter in 1979 and spring and fall in 1980. Seawater collected at the study site and filtered through GFC filters was used to fill duplicate cylinders exposed at each sampling time.

Surface (upper $5 \mathrm{~mm}$ ) sediment samples taken by spatula adjacent to the traps and water samples from the surface of the incoming tide were obtained periodically for comparison of particle sizes and organic content with material trapped in cylinders. Wind was measured during times of trap exposure using a handheld anemometer and water temperature was determined on tidal inundation and during high tide using a glass thermometer.

Cylinders were capped when the tide receded, kept near ambient water temperature and returned to the laboratory. Within $6 \mathrm{~h}$ subsamples of settled particles (ca $0.5 \mathrm{~g}$ dry wt) were transferred as a slurry to four $30 \mathrm{ml}$ glass-stoppered flasks. Filtered $(0.2 \mu \mathrm{m})$ seawater collected at the site and held for several days before use was used to fill flasks, using a siphon to avoid air bubbles. Two pairs of flasks with and without $1 \%$ buffered formalin (to separate chemical uptake from respiration) were incubated for 12 to $24 \mathrm{~h}$ within $2^{\circ} \mathrm{C}$ of ambient temperature with stirring as described in Hargrave et al. (1983). Changes in control flasks without sediment were always $<3 \%$ of initial concentrations.

Dissolved oxygen was measured (precision $\pm 0.05 \mu \mathrm{l}$ $\mathrm{ml}^{-1}$ ) as the mean of two 1 to $2 \mathrm{ml}$ subsamples from each flask using a Radiometer blood gas analyzer. Dissolved carbon dioxide was determined (precision $\pm 0.5 \mu \mathrm{ml}^{-1}$ ) in $20 \mathrm{ml}$ samples by gas partitioning after acidification in a $50 \mathrm{ml}$ syringe using a thermal conductance gas analyzer (Hargrave \& Connolly 1978). Changes in concentrations of both gases during incubations, usually $>15 \%$ of initial values, were linear over periods up to $24 \mathrm{~h}$.

Hourly rates of respiration (after correction for chemical uptake) and carbon dioxide release were expressed as the weight of carbon respired per day by assuming a respiratory quotient of 1 and multiplying hourly rates $\left(\mu \mathrm{l} \mathrm{O}_{2}\right.$ or $\mathrm{CO}_{2} \mathrm{~g}^{-1}$ dry sediment wt $\left.\mathrm{h}^{-1}\right)$ by 24 and by 0.536 to convert to $\mu \mathrm{g} C \mathrm{~g}^{-1} \mathrm{~d}^{-1}$. Decay constants $(k)$ were calculated as the ratio of carbon respiration to organic carbon concentration in settled material. Then $95 \%$ decay times were calculated as $3 / \mathrm{k}$ as discussed above.

Methods for analysis of particulate organic carbon and nitrogen by elemental analyzer and chlorophyll a by fluorometric methods are described in Hargrave et al. (1983). Size spectra of inorganic particles suspended in flood tide water, in surface sediments and in suspended material were determined by Coulter Counter (Kranck \& Milligan 1979). Tubes with overlapping size ranges (2 to $40 \mu \mathrm{m}$ and 10 to $100 \mu \mathrm{m}$ ) were used to measure the size distribution of particles dried and weighed on Millipore ( $\mathrm{HA}$ ) filters before ashing in a low temperature oven and sonified to disaggregate the 
inorganic particles. Concentrations were expressed as weight percent in various size classes.

\section{RESULTS}

\section{Origin of settled material}

Inorganic particles settled in cylinders had a uniform size distribution between 2 and $20 \mu \mathrm{m}$ (Fig. 1). Large inorganic particles $>50 \mu \mathrm{m}$ comprised only 0.5 to $2 \%$ of the dry weight. Inorganic particles from the mud surface were predominantly coarse silt (20 to $50 \mu \mathrm{m})$. In the samples from the open water, coarse silt was only present soon after inundation, on the rising tide. During slack water and ebb tide, the modal inorganic grain size of suspended material was medium silt 15 to $20 \mu \mathrm{m})$. Inorganic particles accumulated in traps had a modal size within this range (10 to $20 \mu \mathrm{m}$ ).

There was no significant relationship between maximum or minimum wind speeds measured throughout the time of trap exposure and organic composition (carbon, nitrogen, chlorophyll a content) in settled particles. Experiments were not conducted during periods of high winds or when ice was present between January and April and more than half of the measurements were made during calm conditions (wind speed $<3 \mathrm{~m}$ $\mathrm{s}^{-1}$ ) (Table 1). While resuspension through wind action could have added variable amounts of bottom sediment to the water column on different sampling days, neither the amount nor organic composition of settled material collected $1 \mathrm{~m}$ above bottom reflected this source of variability.

Organic carbon and nitrogen in trapped particles exceeded concentrations in surface sediment and in suspended particles (Table 1). Enrichment of organic carbon was greater than for nitrogen and thus $C: N$ ratios in settled material were generally higher than those in suspended or sediment particles. Chlorophyll a content in settled material was usually $50 \%$ lower than in surface sediment but values were similar to those in suspension. Carbon: chlorophyll a ratios for settled particles were only slightly higher than values for suspended material but were approximately double the ratios in surface sediment.

\section{Seasonal changes in respiration}

Highest rates of total oxygen uptake (Fig. 2a) and carbon dioxide release (Fig. 2d) occurred between June and August in both years of study. Values for total oxygen uptake in 1980 were significantly greater ( $p$ $<0.05$ ) than in 1979. After correction for chemical demand, rates of oxygen respiration were similar in

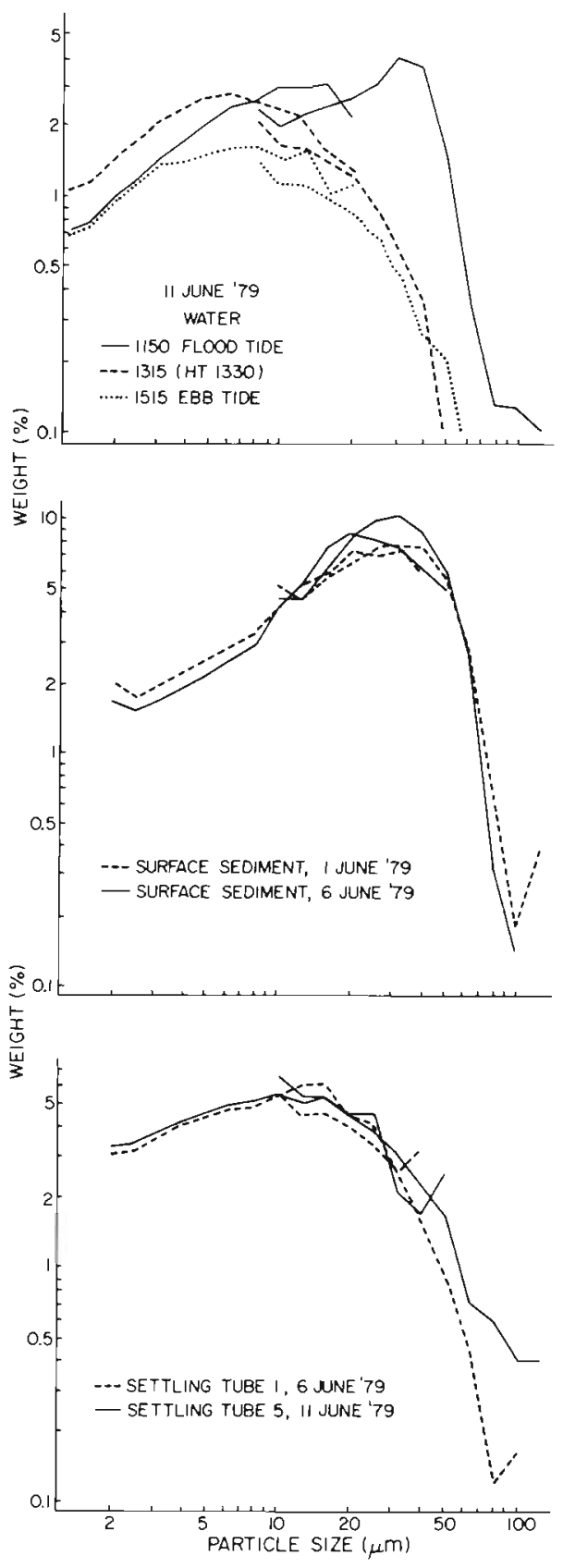

Fig. 1. Size spectra of inorganic particles in suspended, sedimented and settled particles collected during June 1979 at Pecks Cove. Discontinuities in spectra are due to the use of

2 sizes of counting tubes over the particle size range

both years (Fig. 2b). Chemical uptake of oxygen averaged $39 \pm 16 \%$ of the total throughout tive year with no seasonal pattern. There was no significant carbon dioxide release in flasks poisoned with $1 \%$ formalin. Molar ratios of carbon dioxide production : oxygen respiration also showed no clear seasonal pattern. Mean $\pm \mathrm{SD}$ values during summer $(0.8 \pm 0.2)$ were lower than in the fall and winter $(1.3 \pm 0.4)$ but differences were not 
Table 1. Comparison of average (mean of 2 replicates) values for organic carbon, nitrogen (percent of dry weight) and chlorophyll $a\left(\mu \mathrm{g} \mathrm{g}^{-1}\right)$ in particulate matter from Pecks Cove, an intertidal site in Cumberland Basin, upper Bay of Fundy. Suspended matter collected during high tide, settled material collected in cylindrical traps positioned $1 \mathrm{~m}$ above the sediment surface during tidal cover, surficial sediment (upper $5 \mathrm{~mm}$ ) collected during low tide adjacent to traps. -: no data

\begin{tabular}{|c|c|c|c|c|c|c|}
\hline Date & $c$ & $N$ & Chl a & $C: N$ & C:Chl a & $\begin{array}{l}\text { Wind speed } \\
\left(\mathrm{m} \mathrm{s}^{-1}\right)\end{array}$ \\
\hline \multicolumn{7}{|c|}{ Suspended particles } \\
\hline \multicolumn{7}{|l|}{1979} \\
\hline $5 \mathrm{Dec}$ & 0.88 & 0.13 & 5.1 & 6.8 & 1725 & \\
\hline $12 \mathrm{Dec}$ & 0.58 & 0.09 & 3.9 & 6.7 & 1487 & \\
\hline \multicolumn{7}{|l|}{1980} \\
\hline 28 May & 0.94 & 0.13 & 13.7 & 7.5 & 686 & \\
\hline $18 \mathrm{Jun}$ & 0.81 & 0.12 & 19.8 & 7.0 & 1157 & \\
\hline 31 Jul & 0.50 & 0.07 & 25.4 & 7.2 & 197 & \\
\hline 14 Aug & 0.81 & 0.11 & 44.3 & 7.5 & 183 & \\
\hline 5 Sep & 0.75 & 0.10 & 9.8 & 7.4 & 765 & \\
\hline 2 Oct & 0.96 & 0.13 & 19.8 & 7.3 & 485 & \\
\hline \multicolumn{7}{|c|}{ Settled particles } \\
\hline \multicolumn{7}{|c|}{1979} \\
\hline 31 May & 0.17 & 0.23 & 49.3 & 7.2 & 337 & $2.2-4.0$ \\
\hline $23 \mathrm{Jul}$ & 0.11 & 0.15 & 62.9 & 7.5 & 373 & $0-3.1$ \\
\hline 7 Aug & 0.95 & 0.10 & 30.0 & 9.5 & 317 & $0-2.2$ \\
\hline 22 Aug & 0.96 & 0.13 & 49.7 & 7.4 & 379 & $0-2.0$ \\
\hline $6 \mathrm{Sep}$ & 0.91 & 0.07 & 23.0 & 13.0 & 396 & $1.8-2.6$ \\
\hline 5 Oct & 0.13 & 0.18 & 23.2 & 7.2 & 556 & $0-2.0$ \\
\hline 26 Oct & 0.12 & 0.17 & 9.5 & 7.1 & 1263 & $6.6-8.8$ \\
\hline 6 Nov & 0.95 & 0.13 & 5.6 & 7.3 & 1696 & $0-3.5$ \\
\hline 28 Nov & 1.24 & 0.15 & 3.6 & 8.4 & 3444 & $0-2.0$ \\
\hline $5 \mathrm{Dec}$ & 0.92 & 0.13 & - & 7.1 & - & $0-2.2$ \\
\hline $12 \mathrm{Dec}$ & 2.01 & 0.18 & - & 11.2 & - & $2.2-4.5$ \\
\hline \multicolumn{7}{|l|}{1980} \\
\hline $10 \mathrm{Jan}$ & 1.25 & 0.16 & 13.9 & 7.8 & 899 & 0 \\
\hline $28 \mathrm{May}$ & 2.46 & 0.20 & - & 12.4 & - & $0-2.2$ \\
\hline 18 Jun & 1.55 & 0.19 & - & 8.2 & - & $4.4-6.6$ \\
\hline $18 \mathrm{Jul}$ & 0.99 & 0.15 & 49.0 & 6.6 & 202 & $0-1.7$ \\
\hline $31 \mathrm{Jul}$ & 0.99 & 0.15 & 23.3 & 6.6 & 427 & $2.2-3.1$ \\
\hline 14 Aug & 0.96 & 0.13 & 25.3 & 7.4 & 379 & $2.5-4.0$ \\
\hline $5 \mathrm{Sep}$ & 1.02 & 0.14 & 23.0 & 7.3 & 443 & $2.2-4.4$ \\
\hline $2 \mathrm{Oct}$ & 1.01 & 0.10 & 25.7 & 10.1 & 393 & $2.6-3.5$ \\
\hline \multicolumn{7}{|c|}{ Surface sediment } \\
\hline \multicolumn{7}{|c|}{1979} \\
\hline $28 \mathrm{Nov}$ & 0.50 & 0.08 & 7.2 & 6.3 & 694 & \\
\hline $5 \mathrm{Dec}$ & 0.67 & 0.11 & 3.5 & 6.1 & 1914 & \\
\hline $12 \mathrm{DeC}$ & 0.47 & 0.08 & 7.0 & 5.9 & 671 & \\
\hline \multicolumn{7}{|l|}{1980} \\
\hline 28 May & 0.59 & 0.10 & 19.2 & 5.9 & 307 & \\
\hline $18 \mathrm{Jun}$ & 0.59 & 0.10 & 10.2 & 5.9 & 578 & \\
\hline $31 \mathrm{Jul}$ & 0.44 & 0.07 & 13.6 & 6.3 & 324 & \\
\hline 14 Aug & 0.55 & 0.09 & 49.7 & 6.1 & 111 & \\
\hline $5 \mathrm{Sep}$ & 0.60 & 0.10 & 46.1 & 6.0 & 130 & \\
\hline $2 \mathrm{Oct}$ & 0.75 & 0.12 & 147.7 & 6.2 & 51 & \\
\hline
\end{tabular}

significant due to high variance in measurements between July and September.

\section{Effects of temperature and organic content}

Temperature decreased after July in both years (Fig 2c) while organic carbon and nitrogen content in settled particles decreased sharply between June and August (Fig. 3a, b). Minimum values $(\mathrm{C}=0.9 \%, \mathrm{~N}=$ $0.1 \%$ ) reached in August were similar in both years but nitrogen decreased proportionately more than organic carbon. Both elements increased in concentration during fall and winter There was no clear seasonality in $\mathrm{C}: \mathrm{N}$ ratios but short-term variations occurred. Values 

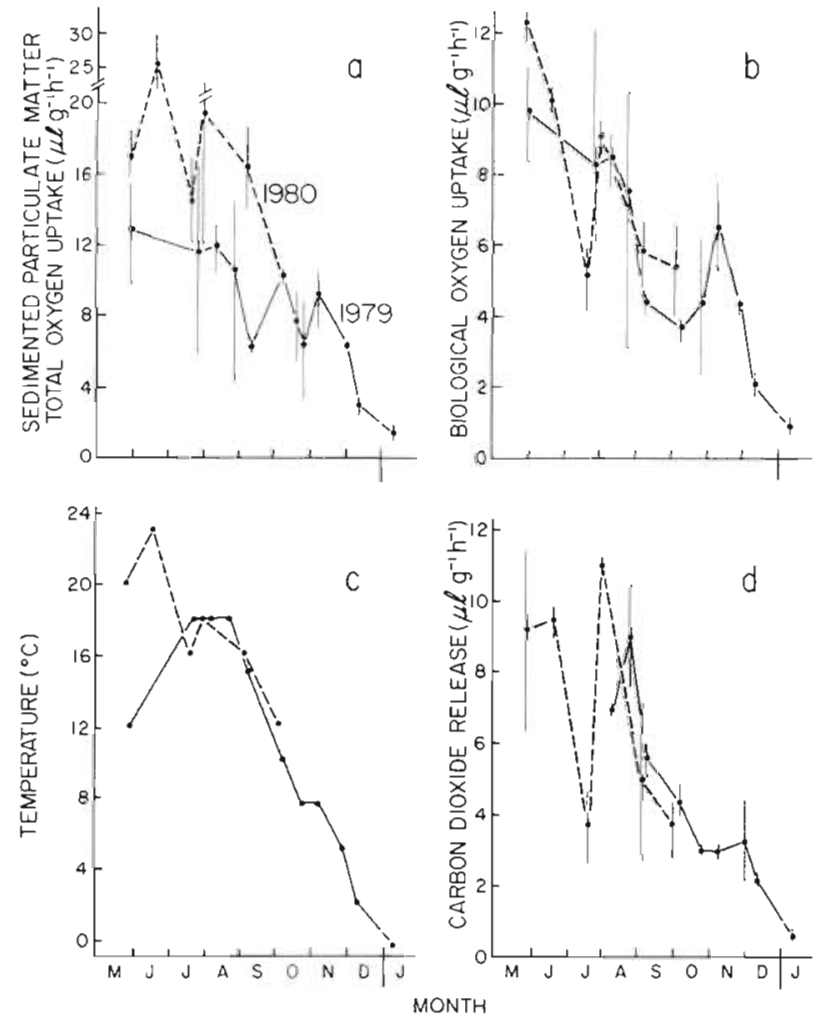

Fig. 2. Seasonal changes in respiration of settled particulate matter collected in replicate sediment traps exposed $1 \mathrm{~m}$ above intertidal sediments during tidal cover at Pecks Cove during 1979 and 1980. (a) Total oxygen uptake; (b) oxygen respiration (total - chemical uptake); (c) incubation temperature; (d) carbon dioxide release. Each point is the mean of 2 determinations

increased ( 7 to 9.5) in July and early August and also between October and December ( 7 to 11 ). Chlorophyll a in settled material was variable during summer (20 to $75 \mu \mathrm{g} \mathrm{g}^{-1}$ ) but generally decreased to minimum values by early winter (Fig. 3c).

Regressions between independent variables (Julian day, temperature, organic carbon, nitrogen and chlorophyll $a$ in settled material) and dependent variables carbon dioxide release and oxygen respiration showed that temperature and chlorophyll a were the only significant variables (Table 2). Stepwise regression indicated that temperature accounted for $68 \%$ of the variance in both oxygen and carbon dioxide respiration. Nitrogen and chlorophyll $a$ in settled material

Table 2. Correlation matrix of coefficients (r) from linear regressions of independent variables (Julian day, JD; temperature, TEMP; chlorophyll $a$, CHL; organic carbon, C; nitrogen, $\mathrm{N}$ ) and dependent variables (carbon dioxide release, $\mathrm{CO}_{2}$; oxygen respiration, $\mathrm{O}_{2}$ ) derived from seasonal measurements of respiration of settled particulate material collected at Pecks Cove. ' $\mathrm{p}<0.05 ; \mathrm{df}=15$

\begin{tabular}{|lrrrrrr|}
\hline & JD & TEMP & $\mathrm{CHL}$ & $\mathrm{C}$ & $\mathrm{N}$ & $\mathrm{CO}_{2}$ \\
\hline TEMP & -0.17 & & & & & \\
$\mathrm{CHL}$ & $-0.45^{\circ}$ & $0.74^{\circ}$ & & & & \\
$\mathrm{C}$ & -0.05 & -0.18 & 0.16 & & & \\
$\mathrm{~N}$ & -0.22 & -0.12 & 0.31 & $0.81^{\circ}$ & & \\
$\mathrm{CO}_{2}$ & -0.24 & $0.84^{*}$ & $0.66^{\circ}$ & -0.007 & 0.01 & \\
$\mathrm{O}_{2}$ & -0.21 & $0.82^{*}$ & $0.62^{\circ}$ & 0.10 & 0.19 & $0.88^{*}$ \\
\hline
\end{tabular}

accounted for an additional $8.8 \%$ and $3.7 \%$ of annual variation, respectively. Only chlorophyll a showed significant seasonal effects indexed by Julian day. Logarithmic transformations did not significantly improve any correlation.

Slope coefficients for linear regressions of temperature on oxygen and carbon dioxide exchange $(0.38 \pm 0.01)$ were not significantly $(p<0.05)$ different. The average slope is equivalent to $a Q_{10}$ of 2 between 2 and $20^{\circ} \mathrm{C}$. Temperature-corrected average respiration rates as carbon dioxide release, normalized to $10^{\circ} \mathrm{C}$, varied from $7.9 \mu \mathrm{l} \mathrm{CO} \mathrm{CO}^{-1} \mathrm{~h}^{-1}$ in late May to $1.5 \mu \mathrm{CO}_{2}$ $\mathrm{g}^{-1} \mathrm{~h}^{-1}$ in October 1979. With the exception of these 2 extreme values, all other measurements averaged $4.1 \pm 0.9 \mu \mathrm{l} \mathrm{CO} \mathrm{g}^{-1} \mathrm{~h}^{-1}$ with no seasonal trend. Normalizing for organic carbon and nitrogen content yielded high rates of carbon respiration $\left(0.3 \mathrm{mg} \mathrm{C} \mathrm{g}^{-1} \mathrm{C}\right.$ $\mathrm{h}^{-1}, 3.1 \mathrm{mg} \mathrm{C} \mathrm{g}^{-1} \mathrm{~N} \mathrm{~h}^{-1}$ ) during late July and August and in early November. Rates at other times were $50 \%$ lower with no seasonal pattern.
Fig. 3. Seasonal changes in organic carbon, nitrogen and chlorophyll a content in particulate matter collected in sediment traps at Pecks Cove. (-) 1979 data, (...) 1980 data (as in Fig. 2). Each point is the mean of 2 determinations
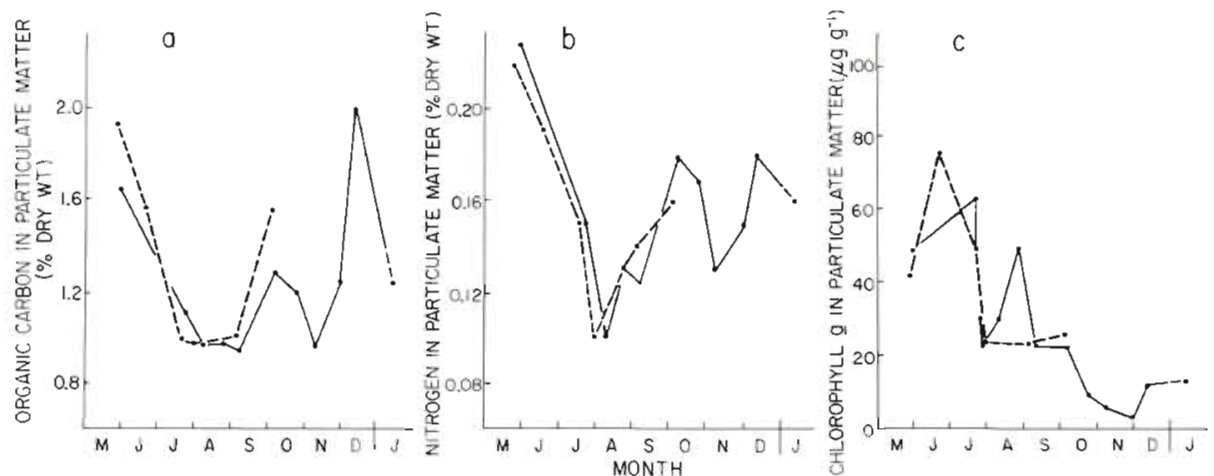
The carbon and nitrogen content of settled particles was low between July and early September, and again in November (Fig. 3a, b). Taken in conjunction with the high normalized rates of respiration that occurred at this time, we infer that there was a component of the organic matter that was resistant to decomposition. Since seasonal minimal values of organic carbon and nitrogen in settled material approached 0.8 and $0.08 \%$ of particulate matter dry weight, respectively, these values were assumed to represent the amount of resistant material present throughout the study period. We have subtracted the refractory portion from the total to calculate the labile fraction.

Our data for carbon: chlorophyll ratios in material from the sediment traps shows a range from about 200 to 3000 when based on total organic carbon, or about 30 to 1000 when calculated from the labile fraction (Fig. 4b). In the July-August period the ratio for our material was about 30 to $50: 1$, which is close to the average value of $40: 1$ for estuarine diatoms found by de Jonge (1980). We therefore conclude that the labile fraction of material in the traps is probably material with a $40: 1$ ratio. We used this assumption to make a separate estimate of the labile fraction. Values during August and early September were similar to those calculated by assuming that the resistant portion of the organic carbon was $0.8 \%$ of the dry weight of settled particles.

Respiration rates normalized on the basis of labile organic carbon (LC) and nitrogen (LN) yielded maximum rates ( $1.7 \mathrm{mg} \mathrm{C} \mathrm{g}^{-1} \mathrm{LC} \mathrm{h}^{-1}, 10.9 \mathrm{mg} \mathrm{C} \mathrm{g}^{-1} \mathrm{LN} \mathrm{h}^{-1}$ ) in late July and August. Values at all other times were lower (means of $0.7 \mathrm{mg} \mathrm{C} \mathrm{g}^{-1} \mathrm{LC} \mathrm{h}^{-1}, 2.9 \mathrm{mg} \mathrm{C} \mathrm{g}^{-1} \mathrm{LN}$ $\left.\mathrm{h}^{-1}\right)$ with minimum rates $\left(0.2 \mathrm{mg} \mathrm{C} \mathrm{g}^{-1} \mathrm{LC} \mathrm{h}^{-1}, 1.5 \mathrm{mg}\right.$ $\mathrm{C} \mathrm{g} \mathrm{LN} \mathrm{h}^{-1}$ ) during December and January.

\section{Organic carbon decay times}

Decay constants ( $\mathrm{k}$ ) and corresponding $95 \%$ decay times $(3 / \mathrm{k})$ in days were calculated (a) for total organic carbon, (b) for labile carbon estimated as total organic carbon $-0.8 \%$ and (c) for labile carbon calculated as chlorophyll a content $\times 40$ (Fig. 4a). Minimum decay times (220 to 289 d) for total organic carbon occurred during August in both years (Fig. 4a) with maximum values ( 780 to $3800 \mathrm{~d}$ ) during winter. A progressive increase in decay times from late July to early October occurred during both years. Decay times based on labile carbon were shorter ( 20 to $100 \mathrm{~d}$ ) in August and early September and increased (200 to 1300 d) during winter (Fig. 4a).

Organic carbon: chlorophyll a ratios (based on total organic carbon or labile carbon) varied seasonally (Fig. 4b). Minimum values (30 to 50) were calculated
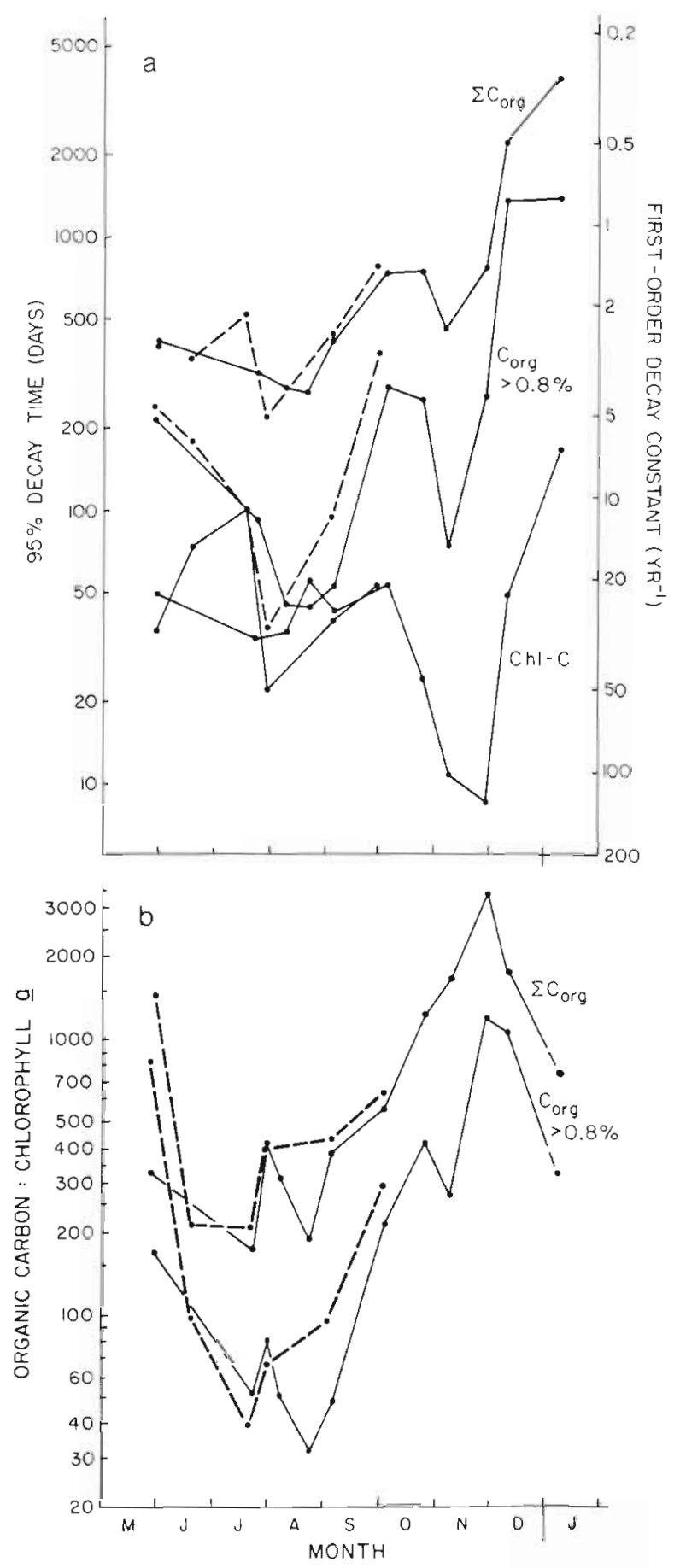

Fig. 4. (a) First-order decay constants (k) for settled particulate matter collected at Pecks Cove. Values of $k$ derived from ratios of total organic carbon, organic carbon $>0.8 \%$ and chlorophyll a content $\times 40$ to daily respiration rates derived as means of carbon respired from measures of oxygen respiration and carbon dioxide release. The decay time to reach $95 \%$ of organic carbon concentration is $3 / \mathrm{k}$ (see Olsen 1963). (b) Organic carbon: chlorophyll a ratios in settled particulate matter based on total organic carbon $>0.8 \%$ 
using labile carbon estimates in July and August coincident with the shortest decay times. Higher ratios occurred earlier and later in the year when decay times were also longer The correlation between labile carbon : chlorophyll a ratio (C: $\mathrm{Chl}$ ) and $95 \%$ decay time (DT in days)

$\log _{10} \mathrm{C}: \mathrm{Chl}=0.67+0.70 \log _{10} \mathrm{DT}(\mathrm{n}=17, \mathrm{r}=0.76)(7)$ was improved by logarithmic transformation of variables.

\section{DISCUSSION}

The uniform inorganic particle size spectra between 2 and $20 \mu \mathrm{m}$ (Fig. 1) indicate that small particles were transported into traps as large flocs (Kranck 1984). Particles were disaggregated for size analysis but they would have settled from suspension as aggregates of smaller particles. Eisma (1986) described the importance of flocculation for aggregation and transport of small particles in estuarine waters. In situ camera observations in the turbid Ems estuary (between the F. R. Germany and the Netherlands) showed that particle clusters up to $1 \mathrm{~mm}$ diameter were present when most constituent particles were $<100 \mu \mathrm{m}$ (Eisma et al. 1984). Few inorganic particles $>50 \mu \mathrm{m}$ were trapped at Pecks Cove even though they were present in surface sediment and in suspension briefly during inundation (Fig. 1). Apparently resuspension did not transport many of these larger particles more than $1 \mathrm{~m}$ above bottom.

The enrichment of small inorganic particles $(<10 \mu \mathrm{m})$ in settled material relative to surface sediment is evident in spectra of inorganic grain size measured between April and December 1979 (Gordon \& Desplanque 1983). This must be partly responsible for the enhanced organic carbon and nitrogen content in settled material (Table 1). The enrichment is consistent with Kranck's (1984) observations which showed that organic matter flocculates with fine inorganic matter to cause higher rates of settling than occur with inorganic or organic particles alone. Tidally resuspended particles collected in near-bottom water of Buzzards Bay (Massachusetts, USA) were also primarily $<20 \mu \mathrm{m}$ and highest concentrations of organic carbon and nitrogen were present in the smallest size category (Roman 1978).

Relations between particle size, type and organic content in surface sediment at Pecks Cove were described by Roberts (1982). Biogenic debris (plant matter, fecal pellets, worm tubes) was enriched with organic carbon and nitrogen relative to sediment particles $<102 \mu \mathrm{m}$. Sediment organic aggregates collected in July were composed of mucus and coaggulated silt particles. They contained organic carbon $(1.55 \%)$ and nitrogen $(0.23 \%)$ in higher concentrations than unfractionated surface sediment. Concentrations are similar to averages for settled particles collected in our study (Table 1).

The most likely origin for particulate matter settled in traps at Pecks Cove is shoreline erosion, resuspension of intertidal sediments and flocculation or precipitation of dissolved organic matter. These processes contribute to the formation of highly turbid water ( 3 to $10 \mathrm{~g} \mathrm{C} \mathrm{m}^{-3}$ ) throughout the upper reaches of the Bay of Fundy (Gordon et al. 1985, Cranford et al. 1987). However, much of this material is refractory to decomposition. The range of oxygen respiration rates we measured $\left(0.5\right.$ to $\left.12 \mu \mathrm{O}_{2} \mathrm{~g}^{-1} \mathrm{~h}^{-1}\right)$ is similar to that observed for 200 to $500 \mu \mathrm{m}$ sand particles with low organic content (Hargrave 1972). Respiration rates of particles from sediment traps in an enriched coastal bay were 100 times greater (Hargrave 1978). This is consistent with the high organic carbon ( 5 to $20 \%$ of dry weight) in the settled material in the bay which was an order of magnitude greater than values at Pecks Cove (Table 1).

Chemical oxygen uptake by settled particles probably reflects consumption by reduced inorganic substances such as manganese or iron and sulphides accumulated from microbial sulphate reduction. Since concentrations of these reduced compounds were not measured there is no direct way to partition chemical oxidation. However, separation of oxygen respiration from this chemical demand allows comparison with $\mathrm{CO}_{2}$ production which is derived from both aerobic and anaerobic microbial metabolism of organic matter.

The molar ratio of $\mathrm{CO}_{2}$ release: $\mathrm{O}_{2}$ respiration near 1 observed in our study indicates that aerobic decomposition predominated. Although ammonia and dissolved organic nitrogen fluxes between sedimented particles and water were not measured, nitrate was consistently released (Keizer et al. 1989). This would be expected in a macrotidal estuary where tidal mixing maintains high levels of dissolved oxygen. Data for dissolved nitrate released reported by Keizer et al. (1989) and rates of $\mathrm{CO}_{2}$ respired reported here were combined to calculated a mean (SD) molar ratio of carbon respired to nitrate-nitrogen released of 25 (27). Values varied from a minimum of 2 during winter to 69 in early summer indicating rapid rates of nitrogen regeneration in the latter period.

Previously published respiration rates of detrital aggregates normalized to organic matter content appear to converge on a narrow range of values. Souza Lima \& Williams (1978) concentrated suspended particulate matter from the estuarine Southampton Water (England) by reverse-flow filtration. Respiration rates during winter (4 to $7 \mathrm{ml} \mathrm{O}_{2} \mathrm{~g}^{-1} \mathrm{C} \mathrm{h}^{-1}$ ), with summer values approximately doubled, can be derived from their data. If organic carbon in particles was 30 to $40 \%$ 
of ash-free dry weight (AFDW), rates are equivalent to 1 to $3 \mathrm{ml} \mathrm{O}_{2} \mathrm{~g}^{-1}$ AFDW h $\mathrm{h}^{-1}$. This is similar to values determined for 100 to $500 \mu \mathrm{m}$ sediment and detrital particles (Hargrave 1972) and for attached microbial communities on diverse solid substrates (Hargrave \& Phillips 1977). Herndl (1988) measured rates of 1 to $3 \mathrm{ml}$ $\mathrm{O}_{2} \mathrm{~g}^{-1}$ AFDW $\mathrm{h}^{-1}$ with marine snow aggregates from the Gulf of Trieste incubated in situ. Values are similar to the average maximum temperature-corrected rate during summer in our study $10.6 \mathrm{ml} \mathrm{O}_{2} \mathrm{~g}^{-1} \mathrm{C} \mathrm{h}^{-1}$ or $1.5 \mathrm{ml} \mathrm{O}_{2} \mathrm{~g}^{-1}$ AFDW $\mathrm{h}^{-1}$ ) assuming a $40 \%$ carbon content.

Our calculations of decay times assume that the only source of respired carbon was through decomposition of particulate matter. Dissolved organic matter present in aged seawater used for incubations was considered to be refractory to decomposition in our short-term experiments. The assumption seems reasonable since decay constants for dissolved organic carbon in coastal seawater stored more than $5 \mathrm{~d}\left(0.3\right.$ to $\left.3 \mathrm{yr}^{-1}\right)$ were an order of magnitude lower than those determined during the first few days after collection (Ogura 1975). Newell et al. (1981) found that $50 \%$ of dissolved organic carbon compounds released from phytoplankton detritus was utilized by bacteria within $1.6 \mathrm{~d}$.

Values for $95 \%$ decay times based on total organic carbon in detritus of $>200 \mathrm{~d}$ (Fig. $4 \mathrm{a}$ ) are inconsistent with changes in organic content in settled debris which occurred rapidly during summer (Fig. 3a, b). Grant \& Hargrave (1987) pointed out that decay times calculated on the basis of total organic carbon will be in error if only a part of the total pool turns over rapidly. Values for particulate organic carbon in surface intertidal sediments of several years or longer have been calculated (Cammen 1975, Hargrave \& Phillips 1981).

Relatively small pools of organic carbon in suspended particles would be expected to have a more rapid turnover. Decay times during summer based on labile carbon (20 to 100 d) (Fig. 4a) are realistic given seasonal fluctuations in organic carbon that we observed. They are within the range of values calculated for the most reactive organic fraction $\left(\mathrm{G}_{01}\right)$ in plankton decomposing under oxic conditions (Westrich $\&$ Berner 1984) and in the top $\mathrm{cm}$ of sediment cores (Grant \& Hargrave 1987).

Rapid decay for labile organic carbon during August ( 45 d) occurs at the time of maximum rates of benthic microalgal production, community respiration, and daily production by the benthic amphipod Corophium volutator at Pecks Cove (Hargrave et al. 1983, Hawkins 1985). Lower decay times ( 8 to 24 d) during November based on carbon calculated from chlorophyll a when levels decreased sharply (Fig. 3c) are suspect. Total organic carbon and nitrogen in settled material increased at this time possibly reflecting supply from salt marsh vegetation which disappears from intertidal areas in the upper Bay of Fundy before the end of November (Cranford et al. 1989). Readily decomposible organic matter should be low in this material (Harrison \& Mann 1975) but organic carbon could remain to be slowly metabolized (Rice 1982).

Acknowledgements. We are grateful to $\mathrm{Mr} \mathrm{T} \mathrm{G}$. Milligan for particle size analysis. Drs K. Kranck and K. Mann commented on the manuscript.

\section{LITERATURE CITED}

Alldredge, A. L., Cohen, Y. (1987). Can microscale chemical patches persist in the sea? A microelectrode study of marine snow. Science 235: 689-691

Azam, F., Fenchel, T., Field, J. G., Gray, J. S., Meyer-Reil, J.-A., Thingstad, F. (1983). The ecological role of water column microbes in the sea. Mar Ecol. Prog. Ser. 10: $257-263$

Berner, R. A. (1980). Early diagenesis: a theoretical approach. Princeton Univ. Press, Princeton

Cadée, G. C. (1978). On the origin of organic matter accumulating on tidal flats of the Balgzand, Dutch Wadden Sea. Hydrobiol. Bull. 12: 145-150

Cammen, L. M. (1975). Accumulation rate and turnover time of organic carbon in a salt marsh sediment. Limnol. Oceanogr. 20: 1012-1014

Cranford, P. J., Gordon, D. C., Jr, Jarvis, C. M. (1989). Measurement of cordgrass, Spartina alterniflora, production in a macrotidal estuary, Bay of Fundy. Estuaries 12: 27-34

Cranford, P. J., Schwinghamer, P., Gordon, D. C., Jr (1987). Identification of microdetritus derived from Spartina and its occurrence in the water column and intertidal sediments of Cumberland Basin, Bay of Fundy. Estuaries 10 : $108-117$

Eisma, D. (1986). Flocculation and de-flocculation of suspended matter in estuaries. Neth. J. Sea Res. 20: 183-199

Eisma, D., Boon, J., Groenewegen, R., Ittekkot, V., Kalf, J., Mook, W G. (1984). Observations of macro-aggregates, particle size and organic composition of suspended matter in the Ems Estuary. Mitt. Geol-Palaeont. Inst. Univ. Hamburg 55

Gordon, D. C., Jr, Desplanque, C. (1983). Dynamics and environmental effects of ice in the Cumberland basin of the Bay of Fundy. Can. J. Fish. Aquat. Sci. 40: 1331-1342

Gordon, D. C., Jr., Keizer, P. D., Dale, J., Cranford, P. J. (1980) Pecks Cove mudflat ecosystem study: observations in 1978. Can. Tech. Rep. Fish. Aquat. Sci. 928: 1-17

Gordon, D. C., Jr, Prouse, N. J., Cranford, P. J. (1985). Occurrence of Spartina macrodetritus in Bay of Fundy waters Estuaries 8: 290-295

Grant, J., Hargrave, B. T (1987). Benthic metabolism and the quality of sediment organic carbon. Biol. Oceanogr. 4: 243-263

Hargrave, B. T (1972). Aerobic decomposition of sediment and detritus as a function of particle surface area and organic content. Limnol. Oceanogr. 17: 583-596

Hargrave, B. T. (1978). Seasonal changes in oxygen uptake by settled particulate matter and sediments in a marine bay. J. Fish. Res. Bd Can. 35: 1621-1628

Hargrave, B. T., Connolly, G. F. (1978). A device to collect supematant water for measurements of the flux of dissolved compounds across sediment surfaces. Limnol. Oceanogr 23: 1005-1010 
Hargrave, B. T., Phillips, G. A. (1977). Oxygen uptake of microbial communities on solid surfaces. In: Cairns, J. (ed.) Aquatic Microbial communities. Garland Publ., New York. p. $545-587$

Hargrave, B. T., Phillips, G. A. (1981). Annual in situ carbon dioxide and oxygen flux across a subtidal marine sediment. Estuar coast. mar. Shelf Sci. 12: 725-737

Hargrave, B. T., Prouse, N. J., Phillips, G. A., Neame, P. A. (1983). Primary production and respiration in pelagic and benthic communities at two intertidal sites in the upper Bay of Fundy. Can. J. Fish. Aquat. Sci. 40 (Suppl. 1): 229-243

Harrison, P. G., Mann, K. H. (1975). Chemical changes during the seasonal cycle of growth and decay in eelgrass (ZOstera marinal on the Atlantic coast of Canada. J. Fish. Res. Bd Can. 32: 615-621

Hawkins, C. M. (1985). Population carbon budgets and the importance of the amphipod Corophium volutator in the carbon transfer on a Cumberland Basin mudflat, upper Bay of Fundy, Canada. Neth. J. Sea Res. 19: 165-172

Herndl, G. J. (1988). Ecology of amorphous aggregations (marine snow) in the Northern Adriatic Sea. II. Microbial density and activity in marine snow and its implication to overall pelagic processes. Mar. Ecol. Prog. Ser 48: $265-275$

Joint, I. R. (1978). Microbial production of an estuarine mudflat. Estuar coast. mar. Sci. 7: 185-195

Jonge, $V$ N. de (1980). Fluctuations in the organic carbon to chlorophyll a ratios for estuarine benthic diatom populations. Mar. Ecol. Prog. Ser 2: 345-353

Keizer, P. D., Hargrave, B. T., Gordon, D. C., Jr (1989). Sediment-water exchange of dissolved nutrients at an intertidal site in the upper Bay of Fundy. Estuaries 12: 1-12

Kranck, K. (1984). The role of flocculation in the filtering of particulate matter in estuaries. In: Kennedy, V. S. (ed.) The estuary as a filter. Academic Press, New York, p. 159-175

This article was presented by Dr G. C. Harding, Dartmouth, Nova Scotia, Canada
Kranck, K., Milligan, T (1979). The use of the Coulter Counter in studies of particle size-distributions in aquatic environments. Bedford Inst. Oceanogr Rep. Ser. BI-R-797. $1-48$

Newell, R. C., Lucas, M. I., Linley, E. A. S. (1981). Rate of degradation and efficiency of conversion of phytoplankton debris by marine micro-organisms. Mar. Ecol. Prog. Ser. 6: $123-136$

Ogura, N. (1975). Further studies on decomposition of dissolved organic matter in coastal seawater. Mar. Biol. 31. $101-111$

Olsen, J. S. (1963). Energy storage and the balance of producers and decomposers in ecological systems. Ecology 44: 322-331

Ribelin, B. W., Collier, A. W (1979). Ecological considerations of detrital aggregates in the salt marsh. In: Livingston, R. J. (ed.) Ecological processes in coastal and marine systems. Plenum Publ., New York, p. 47-68

Rice, D. L. (1982). The detritus nitrogen problem: new observations and perspectives from organic geochemistry. Mar Ecol. Prog. Ser. 9: 153-162

Roberts, D. L. (1982). Distribution of organic carbon and nitrogen in various natural particle types of a fine intertidal sediment. M.Sc. thesis, Dalhousie Univ., Halifax

Roman, M. R. (1978). Tidal resuspension in Buzzards Bay, Massachusetts II. Seasonal changes in the size distribution of chlorophyll, particle concentration, carbon and nitrogen in resuspended particulate matter Estuar. coast. mar Sci. 6: $47-53$

Souza Lima, H. de, Williams, P. J. LeB. (1978). Oxygen consumption by the planktonic population of an estuary Southampton Water Estuar coast. mar Sci. 6: 515-521

Westrich, J. T., Berner, R. A. (1984). The role of sedımentary organic matter in bacterial sulfate reduction: the $G$ model tested. Limnol. Oceanogr 29: 236-249

Manuscript first received: February 22, 1989

Revised version accepted: June 1, 1989 